\title{
Foraging behaviour of red deer Cervus elaphus as a function of the relative availability of two tree species
}

\author{
Nathalie CHEVALLIER-REDOR ${ }^{\mathrm{a}, \mathrm{b}}$, Hélène VERHEYDEN-TIXIER ${ }^{\mathrm{a}}$, \\ Marcel VERDIER ${ }^{\mathrm{b}}$, Bertrand DUMONT ${ }^{\mathrm{b} *}$ \\ a INRA-IRGM, Chemin de Borde-Rouge, Auzeville, BP 27, 31326 Castanet-Tolosan Cedex, France \\ ${ }^{\mathrm{b}}$ INRA-URH, Theix, 63122 Saint-Genès-Champanelle, France
}

(Received 7 February 2000; accepted 14 September 2000)

\begin{abstract}
Cervid populations are rapidly increasing in many part of Western Europe, where they cause damage to forest production. This necessitates a better understanding of what determines their dietary choices. In this experiment, we investigated the relationship between the relative availability of two tree species and diet selection of red deer Cervus elaphus. Three hypotheses were tested: (i) preference for rarity, frequently asserted by foresters, (ii) preference for the more abundant profitable species, as predicted by optimal foraging models, and (iii) frequency-independent selectivity, as already observed in moose and roe deer. Six red deer hinds were therefore observed in shortduration tests when offered two plant species, willow Salix caprea and ash Fraxinus excelsior, in varying proportions. The relation between the relative consumption and availability of the two plant species revealed that red deer prefer ash to willow, and that their short-term selectivity is not a frequency-dependent process. Individual animals differed in the intensity of their preference, but all reacted similarly to variations in the relative availability of the two plant species. Our results advance our understanding of the choices of red deer at the feeding site scale, but further research is needed to propose management practices, which would take advantage of their frequency-independent selectivity.
\end{abstract}

Cervus elaphus / browsing / diet selection / food availability / Salix caprea / Fraxinus excelsior

Résumé - Choix alimentaires du cerf Cervus elaphus selon la disponibilité relative de deux espèces d'arbres. Les populations de Cervidés sont en rapide augmentation en Europe de l'ouest, où elles causent des dégâts à la forêt. Ceci nécessite de mieux comprendre les déterminants de leurs choix alimentaires. Nous avons étudié comment la disponibilité relative de deux espèces d'arbres influence les choix alimentaires du cerf Cervus elaphus en testant trois hypothèses : (i) une sélectivité accrue pour les espèces rares souvent évoquée par les forestiers, (ii) une sélectivité accrue pour l'espèce préférée lorsque son abondance augmente, prédite par les modèles d'optimisation, et (iii) une sélectivité indépendante de la disponibilité relative des espèces végétales comme cela a déjà été montré chez l'élan et le chevreuil. Nous avons pour cela observé les choix alimentaires de six biches dans des tests de courte durée, lorsqu'on faisait varier l'abondance relative du saule Salix caprea par

* Correspondence and reprints

Tel.: 33 (0)4 736246 07; fax: 33 (0)4 736241 18; e-mail: dumont @ clermont.inra.fr 
rapport au frêne Fraxinus excelsior. La relation entre la consommation des deux espèces et leur disponibilité relative indique une préférence du cerf pour le frêne par rapport au saule, et à court terme, une sélectivité indépendante de la disponibilité relative des deux espèces. L'intensité de la préférence pour le frêne variait selon les animaux, mais ceux-ci ont réagi de manière identique aux variations d'abondance des deux espèces. Nos résultats éclairent les choix alimentaires du cerf à l'échelle du site alimentaire, mais d'autres travaux seront nécessaires pour appliquer ces résultats de manière à limiter les dégâts forestiers.

Cervus elaphus / abroutissement / choix alimentaire / disponibilité alimentaire / Salix caprea / Fraxinus excelsior

\section{INTRODUCTION}

Cervids are usually ranked amongst either concentrate selectors (i.e. browsers), which select highly nutritive plant parts (tree and forb leaves, fruits and seeds), or intermediate feeders, which feed on both grasses and browse [16]. Concentrate foods represent $63 \%$ of the diet of the red deer in Europe, including $52 \%$ of browse; this proportion varies according to the animals' habitat but without any clear seasonal pattern [9]. Red deer use a wide range of tree species [8,9], and have also been shown to select and browse saplings according to their morphology and chemical composition $[6,13]$. Due to the increasing size of their populations [7], red deer cause more and more damage to forest production [10, 20], highlighting the need to better understand what determines their dietary choices.

Choice of reforestation (e.g. control of understory vegetation, use of a mixture of saplings) and management techniques (e.g. creation of attractive feeding sites) will influence damage levels through their effect on species availability [10, 22]. Three types of contrasting relationship (Fig. 1) between relative plant availability and consumption have been proposed [19]. In the first one (H0), the animals' selectivity is not a frequency-dependent process. The ratio of plant consumption to its relative availability is constant whether this plant is abundant or rare. The second relationship (H1) is derived from the predictions of optimal foraging models, which have sometimes been confirmed in red deer [17]. An animal will increase its selectivity on the most profitable species as the abundance of this species increases, thus reducing the costs of searching for rarer resources. The third one (H2) is based on a partial-preference hypothesis. Herbivores will eat a mixture of plant species because they search for a balance of nutrients, and because sampling allows them to update their knowledge of food resource in a continually changing environment [18]. Consequently, the rarer a plant species, the higher the selectivity for this species. This last hypothesis has been asserted by foresters because valuable hardwoods, which are usually rare, are thought to suffer from severe damage by deer. These three hypotheses have already been tested on two browsers: the roe deer [22] and the moose Alces alces [19]. In both species, instantaneous selectivity was not a frequency-dependent process (H0). Here we aim to test these hypotheses on the red deer which is more towards the grazing end of herbivore diet spectrum $[9,16]$. Therefore, the choices of six hinds were measured in a cafeteria-type system, in which we varied the relative availability of two tree species.

\section{MATERIALS AND METHODS}

\subsection{Test pen and plant species}

Observations were carried out in a $100 \mathrm{~m}^{2}$ enclosed area of bare ground (Fig. 2). Two 


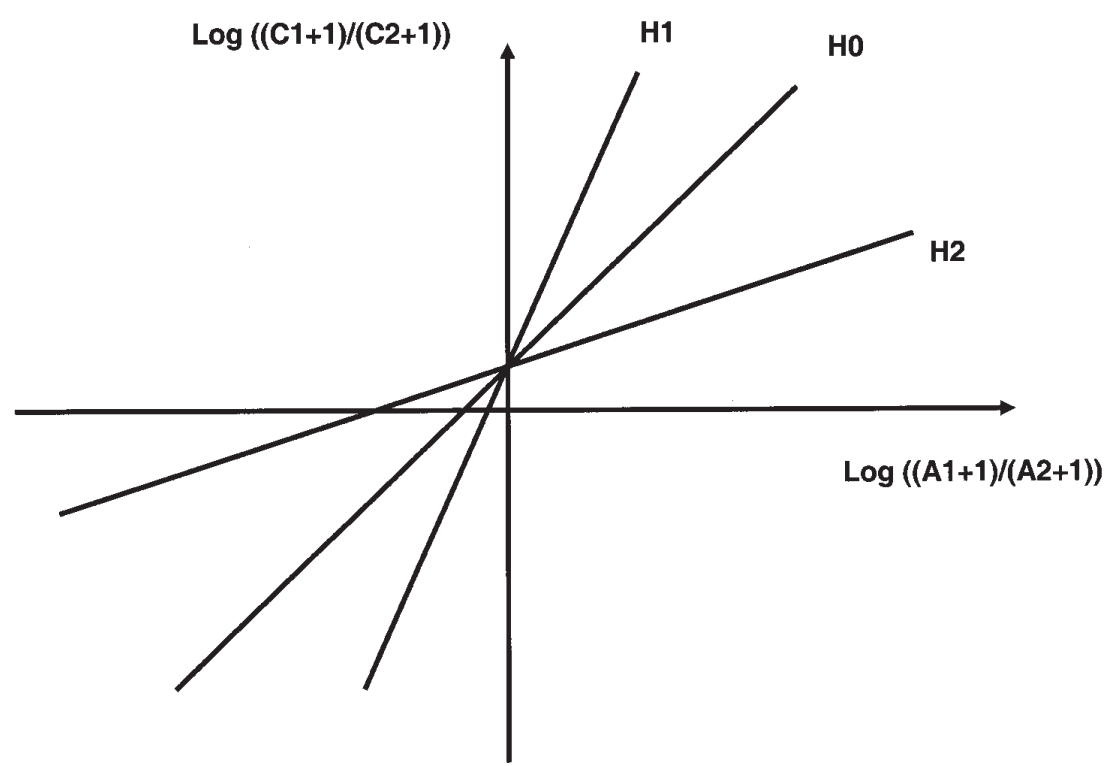

Figure 1. Hypotheses about the relationship between the consumption and relative availability of a plant species, from [19] and [22]. X-axis: ratio between $\log$ of species 1 availability and $\log$ of species 2 availability. Y-axis: ratio between $\log$ of species 1 consumption and $\log$ of species 2 consumption. Species 1 is preferred relative to species 2 if the intercept is $>0$. Under H0, the slope equals to 1 which indicates that diet selection is not a frequency-dependent process. Under H1 (slope > 1), the increase of the selectivity for species 1 is more important than the increase of its relative availability (optimal foraging hypothesis). Under $\mathrm{H} 2$ (slope $<1$ ), the selectivity for species 1 increases as its relative abundance decreases (partial-preference hypothesis).

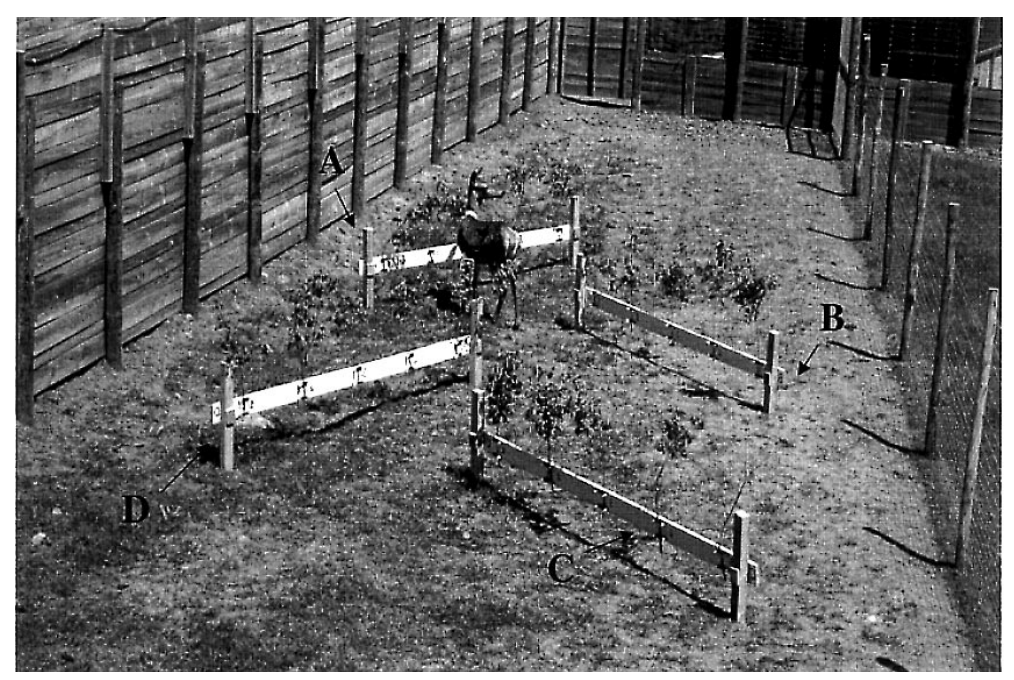

Figure 2. The test arena. The consumption of six hinds was individually recorded with different proportions of ash Fraxinus excelsior and willow Salix caprea offered on four frames. 
plant species were offered on four wooden frames. Five branches in the range of height (from 50 to $100 \mathrm{~cm}$ ) preferentially consumed by red deer hinds [3] were attached on each frame in order to mimic the natural vertical position of saplings. The frames were set up so as to be all clearly visible by the observer. The two plant species, willow Salix caprea and ash Fraxinus excelsior, were chosen because they are both consumed by wild red deer [8-10].

\subsection{Animals}

We used six tame red deer hinds from the INRA farm of Redon (Clermont-Ferrand, France) weighing from 60 to $75 \mathrm{~kg}$ (average: $66 \mathrm{~kg}$ ). They were 1-year-old, familiar with handling and bred together in grass plots with few available trees. In order to accustom them to browse, the tested animals were offered ash and willow branches for six days before the training and testing periods. When observations began, all animals willingly ate the branches. During the training and testing periods the hinds were kept together in an indoor pen, and every evening received $1 \mathrm{~kg}$ of a natural mountain pasture hay $(11 \%$ crude protein, $28 \%$ crude fibre) and $700 \mathrm{~g}$ of pellets $(30 \%$ maize, $30 \%$ beet pulp, $17 \%$ wheat, $12 \%$ soya meal). Food offered outside of the tests supplied $90 \%$ of energy requirements for maintenance [2].

\subsection{Training and testing procedures}

The hinds were trained for one week in order to accustom them to feeding in the test pen. They were individually observed twice a day for a maximum of $15 \mathrm{~min}$, until their consumption of the branches offered on frames was regular. Testing lasted for two weeks. Nine measurement days with two tests each day were conducted. Seven relative availabilities of the two species were tested, each plant species representing 5,
$10,30,50,70,90$ or $95 \%$ of the offered branches. To take into account any shift in behaviour during the testing period, we used a successive sequence design with ash proportion first decreasing from 95 to $5 \%$ and then increasing in the same proportions from 5 to $95 \%$. Each treatment was repeated twice, except for the two extreme values for which there were four replicates in order to change the position of the rare species on the frames.

\subsection{Measurements}

The hinds were tested individually, observation order being randomised each time. We used a microcomputer with our own non commercial software to collect the time spent feeding on each branch. This allowed us to determine the time spent feeding on each of the two species. A test ended when the hind stopped feeding for at least $1.5 \mathrm{~min}$, or when the observer considered that the depletion of one of the species (more than $75 \%$ of leaves consumed) prevented the animal still having a choice. Consequently, foraging duration ranged from 1 to $15 \mathrm{~min}$ (average: $7 \mathrm{~min}$ ). All branches were weighed before and after each test to estimate dry matter consumption. Fresh weight measurements were converted into dry matter from calculations of the dry matter of leaves in each species at the beginning, middle and end of the experiment. Therefore, $30 \mathrm{~g}$ of fresh leaves from each species were collected each time and oven-dried at $60{ }^{\circ} \mathrm{C}$ for $48 \mathrm{~h}$. We used the mean of these three measurements to calculate the hinds' dry matter consumption. To take account of weight losses of branches during the tests, one intact branch of each species was weighed before and after each test.

\subsection{Statistical analyses}

Data were analysed with the relative consumption of ash $\left(\mathrm{C}_{\mathrm{a}}\right)$ and willow $\left(\mathrm{C}_{\mathrm{w}}\right)$ and 
their relative availability $\left(\mathrm{A}_{\mathrm{a}}\right.$ and $\left.\mathrm{A}_{\mathrm{w}}\right)$ expressed as the proportion of the dry matter consumed and offered. A graphical analysis similar to that of Lundberg et al. [19] was performed with the relative consumption of ash to willow $\log \left(\left(\mathrm{C}_{\mathrm{a}}+1\right) /\right.$ $\left.\left(\mathrm{C}_{\mathrm{w}}+1\right)\right)$ expressed as a function of their relative availability $\log \left(\left(\mathrm{A}_{\mathrm{a}}+1\right) /\left(\mathrm{A}_{\mathrm{w}}+1\right)\right)$. Although the variance of the dependent variable is much greater for the lower value of ash availability, we applied the linear model because it is biologically meaningful. The residuals of this linear regression were independent of predicted values (CORR procedure of SAS [21]; $P>0.05)$ and were normally distributed (UNIVARIATE procedure of SAS [21]; $P>0.05)$. Moreover an exponential transformation did not improve the residual variation of the model. Linear regression parameters were estimated. The preference for one of the species was determined by the comparison of the intercept on the Y-axis with zero (no preference). The relationship between plant consumption and relative availability was analysed by testing whether the slope was different from one, a slope of one indicating a frequencyindependent selectivity. The effects of individual animals and of the covariate plant availability on plant consumption were tested using analysis of covariance [21]. Individuals which differed in behaviour were identified by a multiple comparison (Duncan) test. We tested the effect of frame position in the pen on the percentage of consumption on each frame by ANOVA, and differences were detected with the Duncan test. Data were subjected to angular transformation to stabilise variance. This analysis was only performed when ash and willow represented 5 and $95 \%$ of the branches offered, or were equally abundant $(50 \%$ of branches).

\section{RESULTS}

The relationship between plant consumption and relative availability was best described by the equation:

$$
\begin{gathered}
\log \left(\left(\mathrm{C}_{\mathrm{a}}+1\right) /\left(\mathrm{C}_{\mathrm{w}}+1\right)\right) \\
=0.966 \times \log \left(\left(\mathrm{A}_{\mathrm{a}}+1\right) /\left(\mathrm{A}_{\mathrm{w}}+1\right)\right)+0.734 \\
\left(r^{2}=0.58 ; n=108 ; P<0.01 ; \text { Fig. } 3\right) .
\end{gathered}
$$

The intercept was significantly different from zero $\left(\mathrm{F}_{1,107}=105.07 ; P<0.01\right)$, and indicates an average instantaneous preference for ash over willow of $85 \%$. The average slope was not significantly different from one $\left(\mathrm{F}_{1,107}=0.17\right.$; NS), which indicates no effect of plant relative availability on the animals' selectivity.

All hind preferred ash over willow (range: 81 to $96 \%$; $P<0.01$ ) but the covariance analysis showed significant differences between individual animals in the intensity of this preference $\left(\mathrm{F}_{1,6}=2.70 ; P<0.05\right)$. Duncan's multiple comparison test indicated that one hind had a higher relative preference for ash over willow compared to four others $(P<0.05)$. Slopes of individual regressions ranged from 0.62 to 1.11 , none of them being significantly different from one $\left(\mathrm{F}_{1,17}\right.$ from 0.08 to $\left.2.77 ; P>0.10\right)$.

There was a significant effect of the position of frames on how the hinds used them (Fig. 4). Frame D was always less used than frame $A$, the other two frames being exploited at an intermediate level. This justifies the switching of the position of the rare species when only one branch was offered.

\section{DISCUSSION}

There was no effect of the relative availability of the two species on the selectivity of red deer. Both hypotheses $\mathrm{H} 1$ and $\mathrm{H} 2$ were rejected and $\mathrm{H} 0$ was accepted. The hinds neither increased their selectivity on the more profitable species as its abundance increased (as predicted by the Optimal Foraging Theory), nor did they try to vary their diet in order to track changes in their foraging environment (partial-preference hypothesis). This result is consistent with 


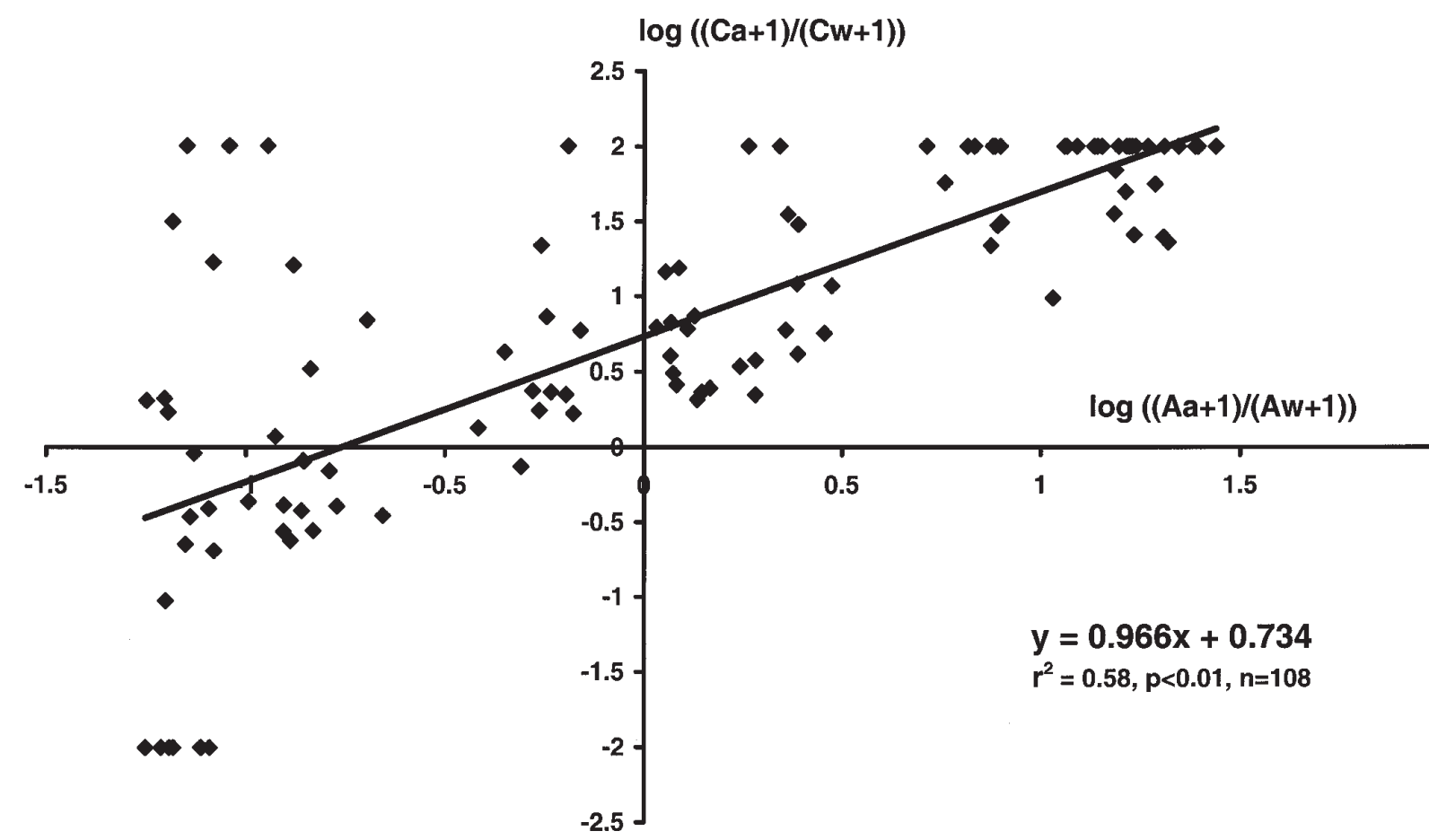

Figure 3. Observed regression between the consumption of ash relative to willow $\log \left(\left(\mathrm{C}_{\mathrm{a}}+1\right) /\left(\mathrm{C}_{\mathrm{w}}+1\right)\right)$ and their relative availability $\log \left(\left(\mathrm{A}_{\mathrm{a}}+1\right) /\left(\mathrm{A}_{\mathrm{w}}+1\right)\right)$. Ash and willow were offered in different proportions to six hinds tested individually in a cafeteria-type system. $A_{a}$ and $A_{w}$ are the relative availability (in dry matter) of ash and willow, respectively. $\mathrm{C}_{\mathrm{a}}$ and $\mathrm{C}_{\mathrm{w}}$ are the relative consumption (in dry matter) of ash and willow, respectively. 

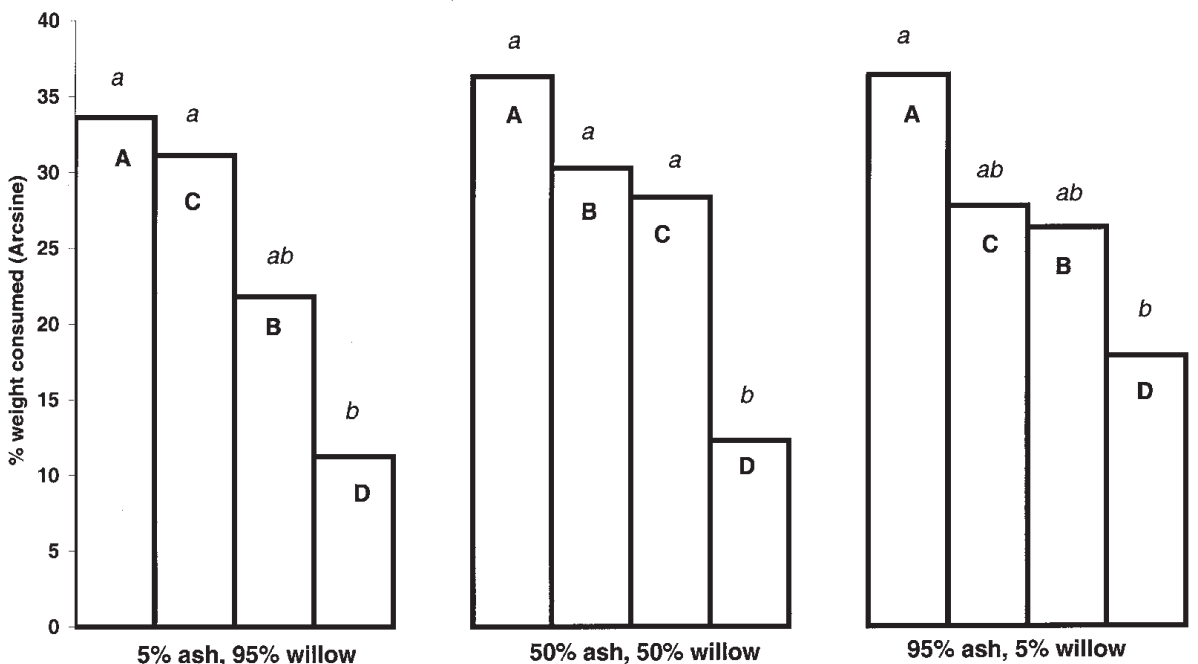

Figure 4. Differences in the mean utilisation (arcsine \% dry matter consumed) of the four frames A, $\mathrm{B}, \mathrm{C}$ and D. Only the results for ash representing 5,50 and $95 \%$ of branches are presented. Within each treatment, means with different letters differ $(P<0.05)$.

observations made on moose [19] and roe deer [22], which showed that these two highly-selective browsers did not increase their selectivity for a preferred species when its relative availability decreased. We observed an instantaneous preference of red deer for ash over willow. One hind differed in the intensity of this preference, but this would have to be confirmed over a longer period, as significant individual variations in preferences observed in short-duration tests can disappear when measurements are conducted over a whole day [4] or longer. Hobbs et al. [15] also observed inter-individual differences in the winter diet of wapiti (Cervus elaphus nelsoni), some animals probably foraging more selectively than others. From the results of our experiment, the H0 hypothesis was accepted for each hind, despite differences in the intensity of individual preference for ash (from 81 to $96 \%$ ), which generalises the conclusion on the frequency-independence of the selectivity of red deer over a wider range of relative preferences.
It could be argued that this frequencyindependence of diet selectivity may be the result of the temporal scale of the measurements. Observations were carried out over a short-time scale, whereas diet selection may result from long-term processes [5]. This short-term scale is however biologically meaningful, as a meal is composed of several foraging bouts. During a bout an herbivore forages on groups of feeding locations located a short distance apart and called 'feeding site', the distance between feeding sites being much greater. Bouts last up to a few minutes in roe deer [12] and in blacktailed deer Odocoileus hemionus sitkensis [11]. In red deer, Hester et al. [14] have estimated that foraging bouts on a grass / heather mosaic last on average 3 minutes. In our experiment, average foraging duration was 7 minutes, which could represent the time deer spend browsing on a feeding site. Our results are thus useful to understand the choices of red deer at this spatial scale.

Our results indicate that the relative consumption of the preferred plants decreased 
as their local relative availability decreased. This finding would need to be tested in commercial plantations but it is likely that, as in roe deer [22], reducing the abundance of commercial trees relative to other food could reduce sapling consumption (dilution effect). This could be achieved by favouring the growth of understory vegetation or by planting a more palatable vegetation prior to the commercial saplings. If the frequency-independence of red deer selectivity still applies at larger spatial scales, another way to reduce the relative availability of saplings would be to provide attractive feeding sites near the plantation. However, this may also have negative consequences as the diversity of plant species could attract deer to these areas [10]. Furthermore, in order to propose management practices that will efficiently reduce the damage of red deer to forest production, there would be a need to test the frequencyindependence of deer selectivity within a group of animals. With wild red deer, low ranking stags switched to less preferred grass patches because they were displaced from their preferred forage by the dominant animals [1]. In plantations, low ranking animals within red deer groups may consume other species that would thus become more prone to damage.

\section{ACKNOWLEDGEMENTS}

We greatly thank C. Mallet and D. Jouve from the INRA farm of Redon for their excellent technical assistance and for their care of the animals. We are also grateful to $\mathrm{Ph}$. Ballon (Cemagref), R. Baumont and D. Pépin for their comments on the manuscript. A.J.M. Hewison and A.-M. Crowley kindly revised the English version of the manuscript.

\section{REFERENCES}

[1] Appleby M.C., Social rank and food access in red deer stags, Behaviour 74 (1980) 294-309.

[2] Brelurut A., Pingard A., Thériez M., Le cerf et son élevage - Alimentation, techniques et pathologie, Editions du Point Vétérinaire, MaisonsAlfort, 1990, 143 p.
[3] Chevallier-Redor N., Influence de la hauteur et de l'abondance relative des espèces végétales sur le comportement alimentaire du cerf élaphe, DAA INA-Paris Grignon, 1999, 40 p.

[4] Dumont B., D'hour P., Petit M., The usefulness of grazing tests for studying the ability of sheep and cattle to exploit reproductive patches of pastures, Appl. Anim. Behav. Sci. 45 (1995) 79-88.

[5] Dumont B., Iason G.R., Can we believe the results of grazing experiments? Issues and limitations in methodology, in: Rook A.J., Penning P.D. (Eds.), Grazing Management: The Principles and Practice of Grazing for Profit and Environmental Gain within Temperate Grassland Systems, BGS Occasional Symposium No. 34, Harrogate, UK, 2000, pp. 171-180.

[6] Duncan A.J., Hartley S.E., Iason G.R., The effect of monoterpene concentrations in Sitka spruce (Picea sitchensis) on the browsing behaviour of red deer (Cervus elaphus), Can. J. Zool. 72 (1994) 1715-1720.

[7] Gaultier P., Tableaux de chasse cerf - chevreuil sanglier. Saison 1997-1998, Bull. Mens. ONC 237 (Suppl.) (1998) 4 p.

[8] Gebcynska Z., Food of the roe deer and red deer in the Bialowieza Primeval Forest, Acta Theriol. 25 (1980) 487-500.

[9] Gebert C., Verheyden-Tixier H., Variations of diet composition of red deer (Cervus elaphus L.) in Europe, Mamm. Rev. 31 (2001) in press.

[10] Gill R.M.A., A review of damage by mammals in North temperate forests: 1. Deer, Forestry 65 (1992) 145-169.

[11] Gillingham M.P., Parker K.L., Hanley T.A., Forage intake by black tailed deer in a natura environment: bout dynamics, Can. J. Zool. 75 (1997) 1118-1128.

[12] Hall S.J.G., Neveu H., Sempéré A.J., Application of a new technique to studying the grazing behaviour of roe deer (Capreolus capreolus), Appl. Anim. Behav. Sci. 46 (1996) 145-157.

[13] Hartley S.E., Iason G.R., Duncan A.J., Hitchcock D., Feeding behaviour of red deer (Cervus elaphus) offered Sitka Spruce saplings (Picea sitchensis) grown under different light and nutrient regimes, Funct. Ecol. 11 (1997) 348-357.

[14] Hester A.J., Gordon I.J., Baillie G.J., Tappin E., Foraging behaviour of sheep and red deer within natural heather / grass mosaics, J. Appl. Ecol. 36 (1999) 133-146.

[15] Hobbs N.T., Baker L.D., Gill R.B., Comparative nutritional ecology of montane ungulates during winter, J. Wildl. Manage. 47 (1983) 1-16.

[16] Hofmann R.R., Digestive physiology of the deer - Their morphophysiological specialisation and adaptation, in: Fennessy P.F., Drew K.R. (Eds.), Biology of Deer Production, Roy. Soc. NZ Bull. 22 (1985) 393-407. 
[17] Jiang Z., Hudson R.J., Optimal grazing of wapit (Cervus elaphus) on grassland: patch and feeding station departure rules, Evol. Ecol. 7 (1993) 488-498.

[18] Langvatn R., Hanley T.A., Feeding-patch choice by red deer in relation to foraging efficiency: an experiment, Oecologia 95 (1993) 164-170.

[19] Lundberg P., Aström M., Danell K., An experimental test of frequency-dependent food selection: winter browsing by moose, Holarctic Ecol. 13 (1990) 177-182.
[20] Putman R.J., Moore N.P. Impact of deer in lowland Britain on agriculture, forestry and conservation habitats, Mamm. Rev. 28 (1998) 141-164.

[21] SAS, SAS/STAT ${ }^{\circledR}$ User's Guide (Release 6.11), SAS Inst. Inc., Cary, NC, 1989.

[22] Verheyden-Tixier H., Duncan P., Ballon P., Guillon N., Selection of hardwood saplings by European roe deer: effects of variation in the availability of palatable species and of understory vegetation, Rev. Ecol. (Terre Vie) 53 (1998) 245-253. 